\title{
The Importance of Small and Medium Enterprises in the Economic Development of Eastern Europe
}

\author{
PETRUNENKO IAROSLAV \\ Department of Economic Law and Procedure \\ National University «Odesa Law Academy» \\ UKRAINE
}

IRYNA KHMARSKA

Department of Economics and Organization of Production

Admiral Makarov National University of Shipbuilding

UKRAINE

\author{
TETIANA TKACHENKO \\ Department of Economics and Entrepreneurship of the Faculty of Management and Marketing \\ National Technical University of Ukraine \\ "Igor Sikorsky Kyiv Polytechnic Institute" \\ UKRAINE
}

HANNA KOPTIEVA

Department of Management and Taxation

National Technical University "Kharkiv Polytechnic Institute"

UKRAINE

\author{
VERONIKA KOMANDROVSKA \\ Economics and Business Technologies Department \\ National Aviation University \\ UKRAINE
}

\begin{abstract}
An important engine of economic development of the country is the development of small and medium enterprises. At the same time, small and medium-sized businesses, being elements of the economic system, have a significant impact on the overall economic growth of the country. Thus, there is a mutual influence of economic units on the economy as a whole. The purpose of the article is to study the impact of small and medium-sized enterprises of small and medium-sized enterprises on the gross domestic product on the example of Eastern European countries. Methods: analysis, description, observation, comparison, generalization, induction, deduction, grouping, systematization, tabular and graphical representation. Results: The level of ease of doing business in Eastern Europe was analyzed according to the Ease of doing business ranking and it was found that the Czech Republic and Poland are among the 40 countries in Eastern Europe ranked 40th and 41st out of 190 possible. It is established that the subjects of small (including microenterprises) and medium-sized enterprises belonging to the non-financial sector, in the structure of all enterprises of the non-financial sector of each of the studied countries occupy more than $90 \%$. It was found that a significant share in the structure of small and medium enterprises in Eastern Europe is occupied by microenterprises, while the share of medium-sized enterprises is the lowest. The results of regression analysis to determine the impact of small and medium enterprises on the economic growth of countries obtained by establishing the dependence of GDP on Turnover of the non-financial business economy by size class of employment. Revealed a high dependence of GDP Turnover of the non-financial business economy by size class of employment in all surveyed countries in Eastern Europe.
\end{abstract}

Key-Words: small and medium enterprises, micro-enterprises, non-financial sector, economic growth, gross domestic product.

Received: January 12, 2021. Revised: July 15, 2021. Accepted: August 1, 2021. Published: August 5, 2021. 


\section{Introduction}

The driving force of economic growth in each country is the development of small and mediumsized enterprises, as small and medium-sized enterprises are more flexible to operate in a competitive environment than large enterprises. Practice shows that a significant share in the structure of production (goods, works, services) of highly developed countries (market economies) is occupied primarily by small and medium enterprises, as evidenced by the size of their gross domestic product (Gross domestic product). As for the countries with economies in transition, these countries are currently actively developing small and medium enterprises in the context of providing state support in the form of financing (subsidizing, lending) activities, adoption of special laws and regulations, ensuring participation in development programs at the national level and at the international level by leading international institutions and organizations.

It should be noted that small and medium enterprises, being elements of the economic system, significantly affect the overall economic growth of the country. Therefore, the role of small and medium enterprises in the economic growth of the country is especially important, which determines the relevance of the subject of this study.

\section{Literature Review}

Examining the problems of economic growth, Kot (2018) argues that a special role in this process is played by small and medium-sized businesses, as they form the basis of economic development not only directly of individual countries, but of also the global economy. Šebestová et al. (2020) also note that small and medium-sized enterprises are the driving force of the country's economic growth and one of the tools to achieve its sustainable development goals. At the same time, Akbarova (2019) notes that small business contributes to the diversification and modernization of the economy, as it affects the growth of resource turnover and the formation and growth of the consumer market in conditions of limited resources and economic downturn.

At the same time, Ribeiro-Soriano (2017) emphasizes the special role of small businesses in the economic and social development of the country, because, according to the scientist, small businesses are tools for the transformation and development of communities. Umadia et al. (2020) according to the results of the research show that the efficiency of not only the national economy but also the world is influenced primarily by the business strategies of small and medium enterprises.

Angelova et al. (2017) note that small and medium enterprises are a special driver of economic processes not only in Bulgaria, on the example of which research is conducted, but also in any other country in the world, so providing optimal conditions for their functioning is the key to competitiveness.

Strazovska et al. (2017) as a result of research note that the results of small and medium enterprises can determine the quality and conditions of doing business. For example, in Slovakia, according to researchers, small and medium-sized enterprises do not have sufficient conditions for doing business effectively due to several problems, including the tax and administrative burden. However, the situation is improving every year - it is facilitated by state support in the form of special legislative conditions and support of the European Union, which in the long run will contribute to the growth of small and medium enterprises and business potential of the country as a whole.

Kowalik et al. (2017), studying the features of the internationalization of small and medium enterprises on the example of Poland and the Czech Republic, argue that such processes have a positive impact on the internationalization of the economy as a whole.

Csiszárik-Kocsir (2017) examines the functioning of Hungarian small and medium-sized enterprises in the context of the impact of the country's financial instability. At the same time, the scientist emphasizes that to improve the socioeconomic situation of small and medium enterprises, it is necessary to develop and implement several programs to finance (credit) their activities, which in the long-run will improve the macroeconomic situation in the country.

Gherghina et al. (2020) examine the development of small and medium-sized enterprises in Romania in the context of the impact of investment and innovation. Researchers note that investment and innovation contribute to the growth of production and increase the efficiency of small and medium enterprises, which, in turn, has a positive impact on the economic development of the country as a whole.

Shokhnekh (2019) notes that small businesses, whose activities are related to 
innovation, influence the development of digitalization of the economy, because, as research shows, today the innovation sphere is developing quite rapidly, which has a positive effect on economic growth. At the same time, Papa et al. (2018) study the impact of social media on the process of knowledge creation and innovation by small and medium enterprises in the context of their involvement in the innovation business process.

Mura et al. (2017) examine the specifics of human resource management in small (including micro-enterprises) and medium-sized enterprises in Hungary, Poland, the Czech Republic, and Slovakia and find that more enterprises are employed in micro-enterprises than in small or medium-sized enterprises. Vlacseková et al. (2017) study the role of small and medium enterprises in the economic growth of Slovakia and note that the level of employment in small and medium enterprises is particularly influenced by the motivating factor. Ivanova (2017) examines the main obstacles to the development of small and medium-sized enterprises in Slovakia, among which are the imperfection of the functioning market and difficulties with financing.

Dobeš (2017) reveals the problem of increasing the competitiveness of small and medium enterprises in the context of state assistance to these processes on the example of the Czech Republic. During the research, the scientist concludes that the role of the state in the system of ensuring the effectiveness of development and increasing competitive advantages not only in the national but also in international markets is manifested through a favorable legal framework governing small and medium enterprises, appropriate conditions for starting and running a business with obtaining in the future the expected results of activities and a favorable competitive environment.

Jaramillo et al. (2018), studying the issues of sustainable development of small and medium enterprises, among the many barriers that hinder the development of small and medium enterprises, highlight the lack of resources, high costs associated with the main activity, low level of business experience.

Ndiaye et al. (2018) argue that an important positive factor influencing employment growth (which is one of the indicators of economic growth in the country) in medium-sized enterprises is the use of e-mail to interact with customers or suppliers. On the other hand, the impact of this factor on small businesses is not significant enough.

Raharjo et al. (2019) emphasize that to ensure the sustainable development of small and medium enterprises, and thus promote the economic growth of the country; a special role is played by the introduction of environmental management principles in small and medium enterprises, which in the long-run will reduce the impact of their activities on the environment. At the same time, Woodard (2021) also emphasizes the importance of small and medium-sized enterprises to carry out activities that do not contradict the principles of environmental protection, in particular, emphasizes the improvement of waste flow management procedures.

According to the literature review on the researched issues, it is established that the issues of the impact of small and medium enterprises on the economic development of Eastern European countries in terms of the practical aspect and effectiveness of such impact remain insufficiently disclosed.

This research aims to study the impact of small and medium-sized enterprises of small and medium-sized enterprises on the gross domestic product on the example of Eastern Europe.

\section{Research tasks:}

- to analyze the level of ease of doing business in Eastern Europe by Ease of doing business ranking;

- to analyze the state of development of small and medium enterprises in the countries of Eastern Europe;

- to conduct a regression analysis to establish the dependence of the variable, which is a key indicator of economic development of the country on the independent variable, as an indicator of the activities of small and medium enterprises on the example of Eastern Europe.

\section{Materials and Methods of Research}

To achieve this goal, several scientific and specific research methods were used, including 1) methods of analysis, description, observation, comparison, and generalization - to reveal the main theoretical and practical aspects of small and medium business development in the context of economic growth in Eastern Europe; 2) methods of induction, deduction, grouping, and systematization - to establish the characteristics of the influence of small and medium enterprises on the economic growth of Eastern Europe; 3) methods of tabular and graphical representation - to depict the state of development of small and medium enterprises in Eastern Europe and determine the impact of small and medium enterprises on economic growth in Eastern Europe. 
The study was conducted on the example of Eastern European countries such as Bulgaria, the Czech Republic, Hungary, Poland, Romania, Slovakia, and Ukraine.

The object of the study is small (including micro-enterprises) and medium-sized enterprises, the main features of which are presented in Commission Recommendation of 6 May 2003 concerning the definition of micro, small and medium-sized enterprises (Text with EEA relevance) (notified under document number C(2003) 1422) OJ L 124, 20.5.2003, p. 36-41 (ES, DA, DE, EL, EN, FR, IT, NL, PT, FI, SV) (EURLex, 2003).

Small and medium-sized enterprises engaged in such economic activities were studied: 1) B: Mining and quarrying; 2) C: Manufacturing; 3) D: Electricity, gas, steam, and air-conditioning supply; 4) E: Water supply; sewerage, waste management, and remediation activities; 5) F: Construction; 6) G: Wholesale and retail trade; repair of motor vehicles and motorcycles; 7) $\mathrm{H}$ : Transportation and storage; 8) I: Accommodation and food service activities; 9) J: Information and communication; 10) L: Real estate activities; 11) M: Professional, scientific and technical activities; 12) $\mathrm{N}$ : Administrative and support service activities; 13) 95: Repair of computers and personal and household goods (Eurostat, 2014).

To determine the impact of small and medium enterprises on the economic development of Eastern Europe, the method of regression analysis was used, according to which the level of dependence of variable $\mathrm{V}$, which characterizes the gross domestic product of each country, on the independent variable $\mathrm{R}$, which characterizes sales of nonfinancial enterprises from the studied countries. A qualitative assessment of the relationship between variables was performed using the Chaddock scale.

The basis of the information base studies were the following indicators: Bank, 2020);

1) Ease of doing business ranking (World

2) Share of small and medium enterprises belonging to the non-financial sector in the structure of all enterprises of the non-financial sector (IMD World Competitiveness Center, 2016, 2020);

3) Number of enterprises in the nonfinancial business economy by size class of employment (Eurostat, 2021), (Derzhavna sluzhba statystyky Ukrainy, 2021);

4) Persons employed in the non-financial business economy by size class of employment (Eurostat, 2021), Number of employees in medium, small and micro enterprises of the non-financial sector (Derzhavna sluzhba statystyky Ukrainy, 2021);

5) Value added of the non-financial business economy by size class of employment (Million euro) (Eurostat, 2021), Value added at the costs of production of medium, small and micro enterprises of the non-financial sector (into Millions EUR according to the official exchange rate of HRN to EUR) (average for the period) (Derzhavna sluzhba statystyky Ukrainy, 2021);

6) GDP - Gross domestic product (Millions EUR) in the market prices (Eurostat, 2021) (GDP for Ukraine (in actual prices)) (into Millions EUR according to the official exchange rate of HRN to EUR (average for the period))) (Derzhavna sluzhba statystyky Ukrainy, 2021);

7) Turnover of the non-financial business economy by size class of employment (Millions EUR) (Eurostat, 2021), (Volume of sold products (goods, services) of small and medium enterprises belonging to the non-financial sector for Ukraine) (into Millions EUR according to the official exchange rate of HRN to EUR (average for the period)) (Derzhavna sluzhba statystyky Ukrainy, 2021).

\section{Research Results}

The analysis of Ease of doing business-ranking indicates that the countries of Eastern Europe occupy relatively high positions in terms of ease of doing business. Thus, as of May 1, 2019, Poland and the Czech Republic received 76.4 and 76.3 points, which gives them a reason to take the 40th and 41st place out of 190 possible (for example, first place in the Ease of doing business ranking was occupied by New Zealand, where the Doing Business score was 86.8 points) (Table 1). Instead, Ukraine's position is the lowest among Eastern European countries, as the Doing Business score was only 70.2 . 
Table 1. Eastern European countries at Ease of doing business ranking

\begin{tabular}{|c|c|c|}
\hline Countries & Rank & Doing Business score \\
\hline Bulgaria & 61 & 72,0 \\
\hline Czech Republic & 41 & 76,3 \\
\hline Hungary & 52 & 73,4 \\
\hline Poland & 40 & 76,4 \\
\hline Romania & 55 & 73,3 \\
\hline Slovakia & 45 & 75,6 \\
\hline Ukraine & 64 & 70,2 \\
\hline
\end{tabular}

Source: World Bank, 2020 (Doing Business 2020).

The study of the dynamics of entrepreneurship in Eastern Europe shows that small and medium enterprises belonging to the non-financial sector in the structure of all enterprises of the non-financial sector of each of the studied countries occupy more

than $90 \%$ (Fig. 2). In Ukraine, compared to other countries - the best indicators of the share of small and medium enterprises in the studied activities, as the share of small and medium enterprises in the period 2016-2018 was $99.93 \%$

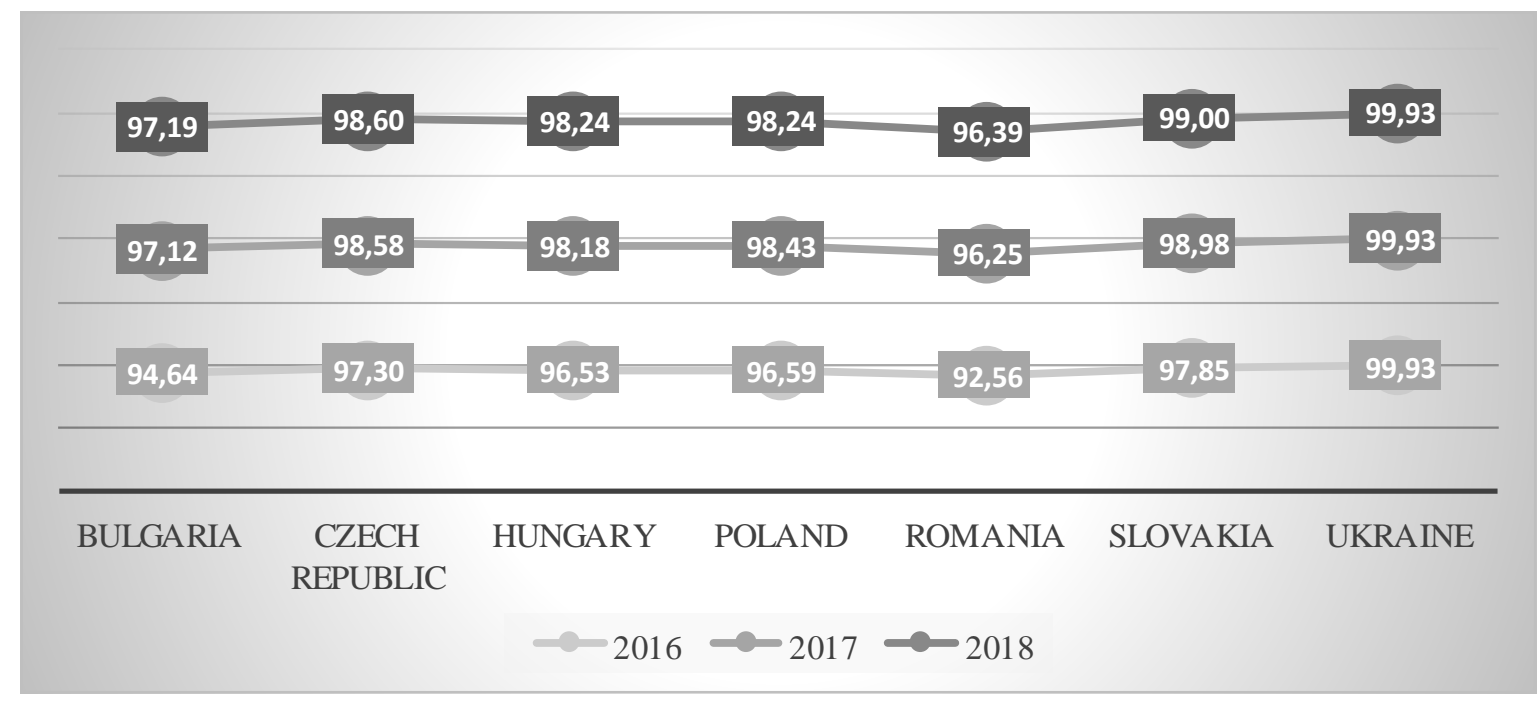

Fig. 1. Share of small and medium-sized enterprises belonging to the non-financial sector in the structure of all enterprises of the non-financial sector in Eastern Europe. Source: IMD World Competitiveness Center, 2016, 2020 .

It is worth noting that in the European Union there are many programs to support small and medium enterprises, as well as special access to finance. The European Union also provides support to small and medium-sized enterprises in Ukraine under the EU4Business initiative (EU4Business, 2021).

A study of the development of small and medium enterprises in Eastern Europe shows that a significant share in the structure of small and medium enterprises is occupied by microenterprises, while the share of medium-sized enterprises is the lowest. The analysis shows that in
2017 in Ukraine and Slovakia the number of microenterprises in the non-financial sector increased by $12.17 \%$ and $5.67 \%$, respectively, compared to the previous year (Table 2). At the same time, in 2018, except for Ukraine, where the number of nonfinancial sector micro-enterprises increased significantly again (by 5.97\% compared to 2017), there were 186449 and 29279 more microenterprises registered in Poland and Hungary than in the previous year. Instead, in 2017, compared to 2016, the share of small businesses in Poland decreased by $5.61 \%$, but in 2018 increased by $56.19 \%$. 
Table 2. The state of development of small and medium enterprises in Eastern Europe

\begin{tabular}{|c|c|c|c|c|c|c|c|c|c|c|c|c|c|}
\hline \multirow{2}{*}{$\mathrm{Ns}$} & \multirow{2}{*}{$\begin{array}{c}\text { Countrie } \\
\mathrm{S}\end{array}$} & \multicolumn{3}{|c|}{2016} & \multicolumn{3}{|c|}{2017} & \multicolumn{3}{|c|}{2018} & \multicolumn{3}{|c|}{2019} \\
\hline & & $0-9$ & $10-49$ & $50-249$ & $0-9$ & $10-49$ & $50-249$ & $0-9$ & $10-49$ & $50-249$ & $0-9$ & $10-49$ & $\begin{array}{l}50- \\
249 \\
\end{array}$ \\
\hline \multicolumn{14}{|c|}{ Number of enterprises in the non-financial business economy by size class of employment } \\
\hline 1 & Bulgaria & $\begin{array}{c}30809 \\
9\end{array}$ & 23012 & 4268 & 311829 & 23693 & 4290 & 315666 & 23082 & 4331 & $\mathrm{n} / \mathrm{a}$ & $\mathrm{n} / \mathrm{a}$ & $\mathrm{n} / \mathrm{a}$ \\
\hline 2 & $\begin{array}{c}\text { Czech } \\
\text { Republic }\end{array}$ & 978289 & 31849 & 6758 & 978967 & 32292 & 6895 & $\begin{array}{c}100185 \\
6\end{array}$ & 32763 & 7057 & $\mathrm{n} / \mathrm{a}$ & $\mathrm{n} / \mathrm{a}$ & $\mathrm{n} / \mathrm{a}$ \\
\hline 3 & Hungary & 518649 & 27172 & 4471 & 536779 & 27775 & 4516 & 566058 & 28033 & 4515 & $\mathrm{n} / \mathrm{a}$ & $\mathrm{n} / \mathrm{a}$ & $\mathrm{n} / \mathrm{a}$ \\
\hline 4 & Poland & $\begin{array}{c}162021 \\
9 \\
\end{array}$ & 56105 & 15273 & $\begin{array}{c}167236 \\
5 \\
\end{array}$ & 52955 & 15501 & $\begin{array}{c}185881 \\
4 \\
\end{array}$ & 82709 & 15474 & $\mathrm{n} / \mathrm{a}$ & $\mathrm{n} / \mathrm{a}$ & $\mathrm{n} / \mathrm{a}$ \\
\hline 5 & Romania & 411905 & 43811 & 8235 & 431910 & 43529 & 8113 & 448714 & 43643 & 7955 & $\mathrm{n} / \mathrm{a}$ & $\mathrm{n} / \mathrm{a}$ & $\mathrm{n} / \mathrm{a}$ \\
\hline 6 & Slovakia & $\begin{array}{c}43290 \\
0\end{array}$ & 10371 & 2454 & 457439 & 11154 & 2517 & 479132 & 11338 & 2567 & $\mathrm{n} / \mathrm{a}$ & $\mathrm{n} / \mathrm{a}$ & $\mathrm{n} / \mathrm{a}$ \\
\hline \multicolumn{14}{|c|}{ Number of medium, small and micro enterprises of the non-financial sector } \\
\hline 7 & Ukraine & 175471 & $\begin{array}{c}2720 \\
3 \\
\end{array}$ & 6941 & 196819 & 27897 & 7085 & $\begin{array}{c}20856 \\
6 \\
\end{array}$ & $\begin{array}{c}2899 \\
5 \\
\end{array}$ & 7438 & $\begin{array}{c}22611 \\
4 \\
\end{array}$ & $\begin{array}{c}3061 \\
4 \\
\end{array}$ & 7793 \\
\hline \multicolumn{14}{|c|}{ Persons employed in the non-financial business economy by size class of employment } \\
\hline 1 & Bulgaria & 592929 & $\begin{array}{c}45527 \\
1 \\
\end{array}$ & $\begin{array}{c}41947 \\
2 \\
\end{array}$ & 559212 & $\begin{array}{c}4690 \\
42 \\
\end{array}$ & $\begin{array}{c}4230 \\
46 \\
\end{array}$ & 600160 & $\begin{array}{c}4580 \\
80 \\
\end{array}$ & $\begin{array}{c}43007 \\
9 \\
\end{array}$ & $\mathrm{n} / \mathrm{a}$ & $\mathrm{n} / \mathrm{a}$ & $\mathrm{n} / \mathrm{a}$ \\
\hline 2 & $\begin{array}{c}\text { Czech } \\
\text { Republic }\end{array}$ & $\begin{array}{c}113452 \\
8 \\
\end{array}$ & $\begin{array}{c}6344 \\
90 \\
\end{array}$ & $\begin{array}{c}69621 \\
1 \\
\end{array}$ & $\begin{array}{c}113583 \\
9 \\
\end{array}$ & $\begin{array}{c}6464 \\
07 \\
\end{array}$ & $\begin{array}{c}7063 \\
03 \\
\end{array}$ & $\begin{array}{c}114703 \\
1 \\
\end{array}$ & $\begin{array}{c}6545 \\
30 \\
\end{array}$ & $\begin{array}{c}72220 \\
9 \\
\end{array}$ & $\mathrm{n} / \mathrm{a}$ & $\mathrm{n} / \mathrm{a}$ & $\mathrm{n} / \mathrm{a}$ \\
\hline 3 & Hungary & 905522 & $\begin{array}{c}51177 \\
1 \\
\end{array}$ & $\begin{array}{c}4430 \\
80 \\
\end{array}$ & 896754 & $\begin{array}{c}52341 \\
3 \\
\end{array}$ & $\begin{array}{c}4494 \\
86 \\
\end{array}$ & 938495 & $\begin{array}{c}5284 \\
24 \\
\end{array}$ & $\begin{array}{c}45122 \\
2 \\
\end{array}$ & $\mathrm{n} / \mathrm{a}$ & $\mathrm{n} / \mathrm{a}$ & $\mathrm{n} / \mathrm{a}$ \\
\hline 4 & Poland & $\begin{array}{c}3375 / 8 \\
8 \\
\end{array}$ & 1176411 & $\begin{array}{c}159189 \\
1 \\
\end{array}$ & $\begin{array}{c}348138 \\
7 \\
\end{array}$ & $\begin{array}{c}113450 \\
9 \\
\end{array}$ & $\begin{array}{c}162321 \\
7 \\
\end{array}$ & $\begin{array}{c}334738 \\
9 \\
\end{array}$ & $\begin{array}{c}164026 \\
2 \\
\end{array}$ & $\begin{array}{c}159848 \\
6 \\
\end{array}$ & $\mathrm{n} / \mathrm{a}$ & $\mathrm{n} / \mathrm{a}$ & $\mathrm{n} / \mathrm{a}$ \\
\hline 5 & Romania & $\begin{array}{c}90065 \\
6 \\
\end{array}$ & $\begin{array}{c}8667 \\
20 \\
\end{array}$ & $\begin{array}{c}8326 \\
77 \\
\end{array}$ & 921117 & $\begin{array}{c}8632 \\
09 \\
\end{array}$ & $\begin{array}{c}8249 \\
77 \\
\end{array}$ & 943328 & $\begin{array}{c}8652 \\
09 \\
\end{array}$ & $\begin{array}{c}80894 \\
1 \\
\end{array}$ & $\mathrm{n} / \mathrm{a}$ & $\mathrm{n} / \mathrm{a}$ & $\mathrm{n} / \mathrm{a}$ \\
\hline 6 & Slovakia & 631580 & $\begin{array}{c}1448 \\
88 \\
\end{array}$ & $\begin{array}{c}25144 \\
4 \\
\end{array}$ & 675515 & $\begin{array}{c}15799 \\
2 \\
\end{array}$ & $\begin{array}{c}25726 \\
4 \\
\end{array}$ & 698576 & $\begin{array}{c}1606 \\
86 \\
\end{array}$ & $\begin{array}{c}26181 \\
4 \\
\end{array}$ & $\mathrm{n} / \mathrm{a}$ & $\mathrm{n} / \mathrm{a}$ & $\mathrm{n} / \mathrm{a}$ \\
\hline \multicolumn{14}{|c|}{ Number of employees in medium, small and micro enterprises of the non-financial sector } \\
\hline 7 & Ukraine & 513650 & $\begin{array}{c}128970 \\
5 \\
\end{array}$ & $\begin{array}{c}171424 \\
3 \\
\end{array}$ & 577001 & $\begin{array}{c}134218 \\
5 \\
\end{array}$ & $\begin{array}{c}183322 \\
6 \\
\end{array}$ & 373231 & $\begin{array}{c}134145 \\
0\end{array}$ & 1833667 & $\begin{array}{c}64566 \\
3 \\
\end{array}$ & $\begin{array}{c}14350 \\
01 \\
\end{array}$ & $\begin{array}{c}18227 \\
39 \\
\end{array}$ \\
\hline \multicolumn{14}{|c|}{ Value-added of the non-financial business economy by size class of employment (Million euro) } \\
\hline 1 & Bulgaria & 5026,4 & $\begin{array}{c}5023 \\
7 \\
\end{array}$ & $\begin{array}{c}5645 \\
8 \\
\end{array}$ & 5706,9 & $\begin{array}{c}5534 \\
0\end{array}$ & $\begin{array}{c}6067 \\
9\end{array}$ & 6177,5 & $\begin{array}{c}5766 \\
6 \\
\end{array}$ & $\begin{array}{c}6768, \\
6 \\
\end{array}$ & $\mathrm{n} / \mathrm{a}$ & $\mathrm{n} / \mathrm{a}$ & $\mathrm{n} / \mathrm{a}$ \\
\hline 2 & $\begin{array}{c}\text { Czech } \\
\text { Republic }\end{array}$ & 18118,9 & 13763,7 & $\begin{array}{c}19966 \\
2 \\
\end{array}$ & $\begin{array}{c}20273 \\
5 \\
\end{array}$ & 15866,3 & $\begin{array}{c}20974 \\
8 \\
\end{array}$ & $\begin{array}{c}22588, \\
9 \\
\end{array}$ & $\begin{array}{c}16983 \\
3 \\
\end{array}$ & 23488,8 & $\mathrm{n} / \mathrm{a}$ & $\mathrm{n} / \mathrm{a}$ & $\mathrm{n} / \mathrm{a}$ \\
\hline 3 & Hungary & $\begin{array}{c}10284 \\
7 \\
\end{array}$ & $\begin{array}{c}9556 \\
2 \\
\end{array}$ & 10457,1 & 11898,1 & 10773,6 & 11709,3 & 14647,3 & $\begin{array}{c}12340 \\
0\end{array}$ & 12409,8 & $\mathrm{n} / \mathrm{a}$ & $\mathrm{n} / \mathrm{a}$ & $\mathrm{n} / \mathrm{a}$ \\
\hline 4 & Poland & $\begin{array}{c}32543 \\
3\end{array}$ & $\begin{array}{c}25698 \\
2 \\
\end{array}$ & 411854 & 38121,2 & $\begin{array}{c}27078 \\
6 \\
\end{array}$ & 43527,1 & $\begin{array}{c}40936 \\
6 \\
\end{array}$ & $\begin{array}{c}40166 \\
4\end{array}$ & 45410,7 & $\mathrm{n} / \mathrm{a}$ & $\mathrm{n} / \mathrm{a}$ & $\mathrm{n} / \mathrm{a}$ \\
\hline 5 & Romania & 9776,3 & $\begin{array}{c}10860, \\
5 \\
\end{array}$ & $\mathrm{n} / \mathrm{a}$ & 10615,7 & 12515,6 & $\mathrm{n} / \mathrm{a}$ & 13325,3 & 13373,8 & 13754,8 & $\mathrm{n} / \mathrm{a}$ & $\mathrm{n} / \mathrm{a}$ & $\mathrm{n} / \mathrm{a}$ \\
\hline 6 & Slovakia & 7921,3 & $\begin{array}{c}5008, \\
9\end{array}$ & $\begin{array}{c}6514 \\
1\end{array}$ & 8663,9 & $\begin{array}{c}5319 \\
0\end{array}$ & $\begin{array}{c}6922 \\
2\end{array}$ & 9091,2 & $\begin{array}{c}5860, \\
5\end{array}$ & $\begin{array}{c}7450 \\
4\end{array}$ & $\mathrm{n} / \mathrm{a}$ & $\mathrm{n} / \mathrm{a}$ & $\mathrm{n} / \mathrm{a}$ \\
\hline \multicolumn{14}{|c|}{$\begin{array}{l}\text { Value-added at the costs of production of medium, small and micro enterprises of the non-financial } \\
\text { sector (into Millions EUR according to the official exchange rate of HRN to EUR) (average for the } \\
\text { period) }\end{array}$} \\
\hline 7 & Ukraine & 24,1 & 49,1 & 174,9 & 33,2 & 60,8 & 218,3 & 40,2 & 69,1 & 218,0 & 64,1 & 96,5 & $\begin{array}{c}275 \\
9\end{array}$ \\
\hline
\end{tabular}

Source: Eurostat, 2021a; 2021b; 2021c; Derzhavna sluzhba statystyky Ukrainy, 2021a; 2021b; 2021c.

An analysis of the structure of employment in non-financial sector enterprises shows that the largest number of employees in the surveyed member states of the European Union is employed in micro-enterprises. In Ukraine, there is another trend, as a significant share in the structure of employment in non-financial sector enterprises is occupied by medium-sized enterprises. Regarding the dynamics of change in this indicator, in 2017, compared to 2016 , there was a decrease in the number of employees in micro-enterprises in Bulgaria - by 5.69\% (although in 2018 this figure increased by $7.32 \%$ ), in 2018 - in Poland - by $3.85 \%$ and in Ukraine - by $35.32 \%$ - (in 2017, the figure increased by $12.33 \%$ ). On the other hand, in 2017 the number of employees in small enterprises in Slovakia increased significantly (by $9.04 \%$ ), and in 2018 - in Poland (by 44.58\%). 
Another key indicator of the development of small and medium enterprises is a benefit of production costs. Thus, among the studied countries of Eastern Europe, the highest value-added by production costs had micro-enterprises, small and medium-sized enterprises in the Czech Republic and Poland. In contrast, in Ukraine, this figure is many times lower than in other Eastern European countries.
To determine the impact of small and medium enterprises on the economic development of Eastern Europe, a regression analysis was performed between the dependent variable GDP (GDP for Ukraine) and the independent variable R (Volume of sold products (goods, services) of small and medium enterprises belonging to the nonfinancial sector of Ukraine) (Table 3).

Table 3. Input data for regression analysis

\begin{tabular}{|c|c|c|c|c|c|c|c|c|c|c|c|c|c|}
\hline \multirow{2}{*}{ № } & \multirow{2}{*}{$\begin{array}{c}\text { Countrie } \\
\mathrm{S}\end{array}$} & \multicolumn{2}{|c|}{2014} & \multicolumn{2}{|c|}{2015} & \multicolumn{2}{|r|}{2016} & \multicolumn{2}{|c|}{2017} & \multicolumn{2}{|c|}{2018} & \multicolumn{2}{|c|}{2019} \\
\hline & & GDP1 & R1 & GDP2 & R2 & GDP3 & R3 & GDP4 & $\mathrm{R} 4$ & GDP5 & R5 & GDP6 & R6 \\
\hline 1 & Bulgaria & $\begin{array}{c}42890 \\
3\end{array}$ & 79139,4 & $\begin{array}{c}45690, \\
9 \\
\end{array}$ & $\begin{array}{c}84798 \\
2 \\
\end{array}$ & $\begin{array}{c}48640, \\
2\end{array}$ & $\begin{array}{c}84282 \\
4\end{array}$ & $\begin{array}{c}52329, \\
0\end{array}$ & $\begin{array}{c}91862, \\
5 \\
\end{array}$ & 56111,8 & $\begin{array}{c}95578 \\
9\end{array}$ & $\mathrm{n} / \mathrm{a}$ & $\mathrm{n} / \mathrm{a}$ \\
\hline 2 & & $\begin{array}{c}157821 \\
3 \\
\end{array}$ & $\begin{array}{c}244657 \\
, 8\end{array}$ & $\begin{array}{c}169558 \\
, 2 \\
\end{array}$ & $\begin{array}{c}252774 \\
, 4 \\
\end{array}$ & $\begin{array}{c}177438, \\
5 \\
\end{array}$ & $\begin{array}{c}251746 \\
1\end{array}$ & $\begin{array}{c}194132 \\
9\end{array}$ & $\begin{array}{c}274383 \\
, 6 \\
\end{array}$ & $\begin{array}{c}210927 \\
, 8 \\
\end{array}$ & $\begin{array}{c}295845 \\
, 8\end{array}$ & $\mathrm{n} / \mathrm{a}$ & $\mathrm{n} / \mathrm{a}$ \\
\hline 3 & $\begin{array}{l}\text { Hungar } \\
\text { y }\end{array}$ & $\begin{array}{c}106061 \\
, 3\end{array}$ & $\begin{array}{c}151509 \\
9\end{array}$ & $\begin{array}{c}112701, \\
0\end{array}$ & $\begin{array}{c}158505 \\
, 1\end{array}$ & $\begin{array}{c}116129 \\
8\end{array}$ & $\begin{array}{c}159374 \\
6\end{array}$ & $\begin{array}{c}126891 \\
0\end{array}$ & $\begin{array}{c}177046 \\
5\end{array}$ & $\begin{array}{c}135941, \\
4\end{array}$ & $\begin{array}{c}185261 \\
1\end{array}$ & $\mathrm{n} / \mathrm{a}$ & $\mathrm{n} / \mathrm{a}$ \\
\hline 4 & Poland & $\begin{array}{c}408967 \\
8\end{array}$ & $\begin{array}{c}492071 \\
, 5\end{array}$ & $\begin{array}{c}430465 \\
, 8 \\
\end{array}$ & $\begin{array}{c}516402 \\
, 8 \\
\end{array}$ & $\begin{array}{c}427091 \\
, 8\end{array}$ & $\begin{array}{c}515443 \\
6\end{array}$ & $\begin{array}{c}467426 \\
, 6\end{array}$ & $\begin{array}{c}65590 \\
, 0\end{array}$ & $\begin{array}{c}497842 \\
, 3 \\
\end{array}$ & $\begin{array}{c}631304 \\
, 8\end{array}$ & $\mathrm{n} / \mathrm{a}$ & $\mathrm{n} / \mathrm{a}$ \\
\hline 5 & $\begin{array}{l}\text { Romani } \\
\text { a }\end{array}$ & $\begin{array}{c}150708 \\
, 6 \\
\end{array}$ & $\begin{array}{c}143466 \\
, 7\end{array}$ & $\begin{array}{c}160149, \\
8 \\
\end{array}$ & $\begin{array}{c}155589, \\
5 \\
\end{array}$ & $\begin{array}{c}170063 \\
, 4\end{array}$ & $\begin{array}{c}158475, \\
2 \\
\end{array}$ & $\begin{array}{c}187772, \\
7\end{array}$ & $\begin{array}{c}169184, \\
8 \\
\end{array}$ & $\begin{array}{c}204496 \\
, 9 \\
\end{array}$ & $\begin{array}{c}174938 \\
6 \\
\end{array}$ & $\mathrm{n} / \mathrm{a}$ & $\mathrm{n} / \mathrm{a}$ \\
\hline 6 & Slovakia & $\begin{array}{c}73269 \\
8\end{array}$ & $\begin{array}{c}95433 \\
2\end{array}$ & $\begin{array}{c}79767 \\
6 \\
\end{array}$ & $\begin{array}{c}102354 \\
\quad, 6 \\
\end{array}$ & & $\begin{array}{c}107333 \\
, 4\end{array}$ & $\begin{array}{c}84532 \\
2\end{array}$ & $\begin{array}{c}114929, \\
5 \\
\end{array}$ & $\begin{array}{c}89505, \\
5 \\
\end{array}$ & $\begin{array}{c}121011 \\
9\end{array}$ & $\mathrm{n} / \mathrm{a}$ & $\mathrm{n} / \mathrm{a}$ \\
\hline & Ukraine & 1009,8 & 1336,5 & 820,7 & 1094,0 & 843,1 & 1140,6 & 994,5 & 1378,9 & 1107,7 & 1533,5 & 1374, & 700 \\
\hline
\end{tabular}

Source: Eurostat, 2021d; Eurostat, 2021e; Derzhavna sluzhba statystyky Ukrainy, 2021d; 2021e.

In the context of the calculation, the value of the coefficient of determination (R-square) was obtained, the level of dependence of the variable GDP on the independent variable $\mathrm{R}$ was determined
(Chaddock scale was used to qualitatively estimate the density of the relationship between variables) (Table 4).

Table 4. The results of regression analysis

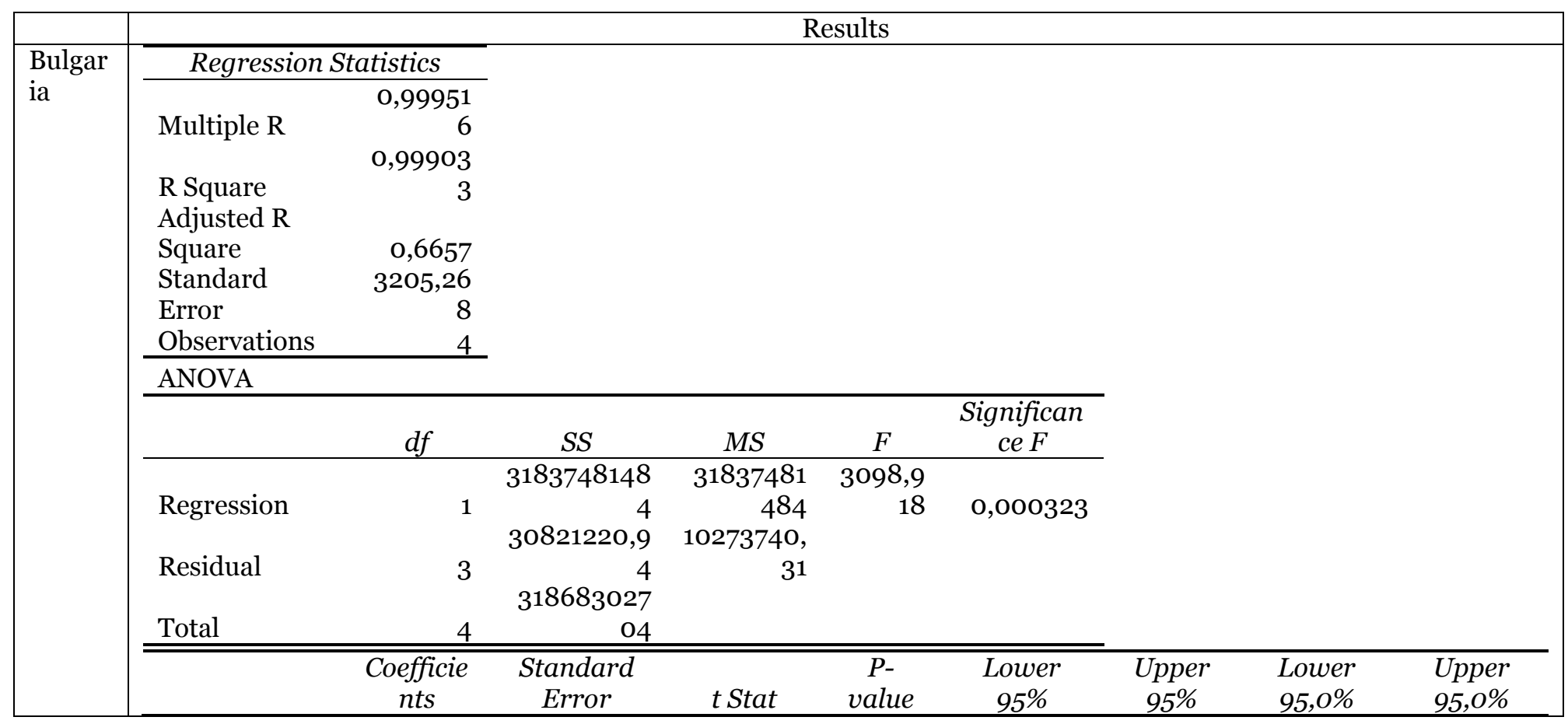




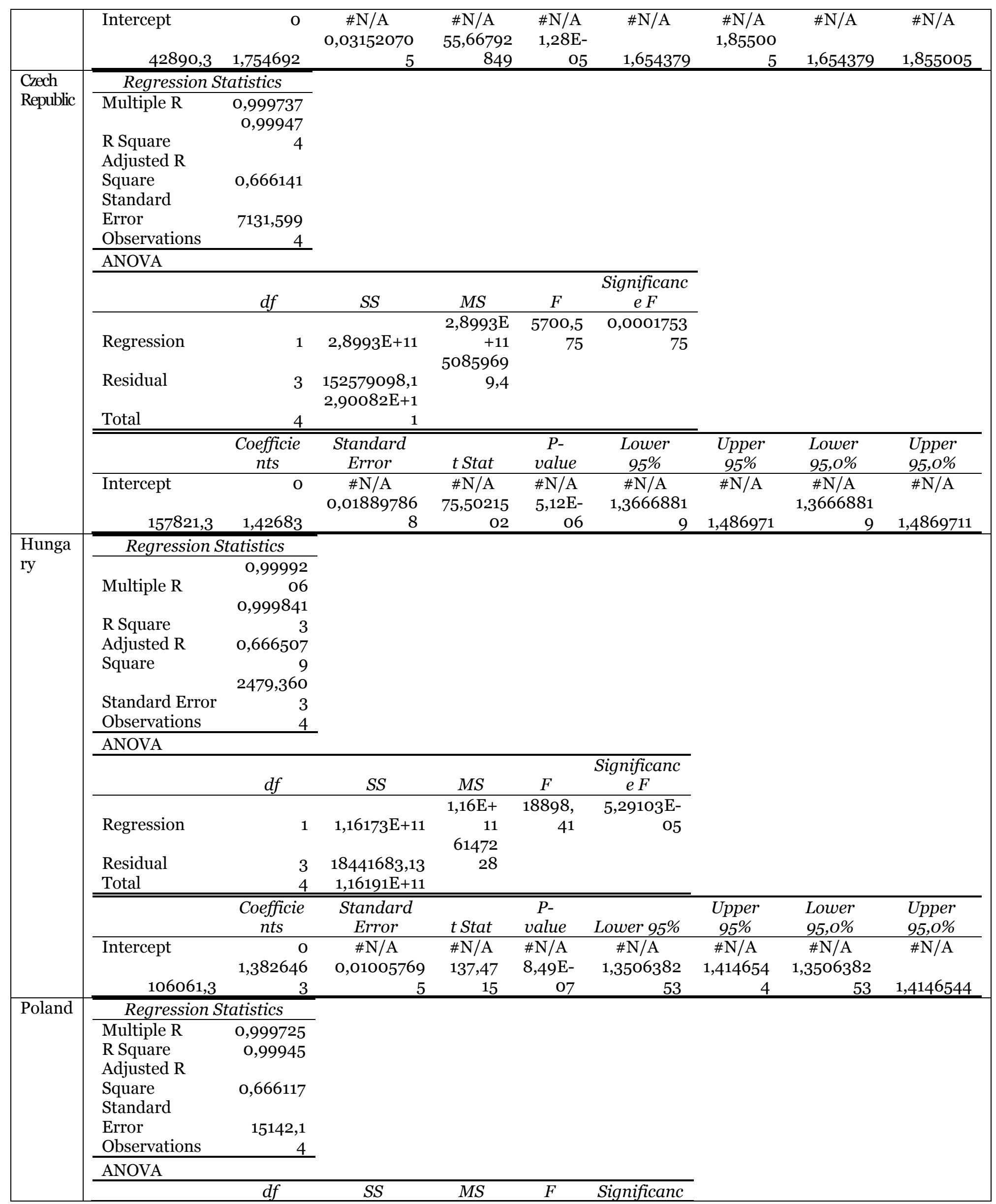




\begin{tabular}{|c|c|c|c|c|c|c|c|c|c|}
\hline \multirow{18}{*}{$\begin{array}{l}\text { Ukrain } \\
\text { e }\end{array}$} & \multicolumn{2}{|c|}{ Regression Statistics } & & & & & & & \\
\hline & Multiple R & $\begin{array}{r}0,991145 \\
0,98236\end{array}$ & & & & & & & \\
\hline & R Square & & & & & & & & \\
\hline & Adjusted R & & & & & & & & \\
\hline & $\begin{array}{l}\text { Square } \\
\text { Standard }\end{array}$ & 0,976491 & & & & & & & \\
\hline & Error & 43,90631 & & & & & & & \\
\hline & Observations & & & & & & & & \\
\hline & ANOVA & & & & & & & & \\
\hline & & $d f$ & $S S$ & $M S$ & $F$ & $\begin{array}{c}\text { Significanc } \\
\text { e F }\end{array}$ & & & \\
\hline & & & 322226,296 & 322226 & 167,150 & 0,0009989 & & & \\
\hline & Regression & 1 & 4 & $\begin{array}{r}, 3 \\
1927,76\end{array}$ & 3 & 3 & & & \\
\hline & Residual & 3 & 5783,291596 & 4 & & & & & \\
\hline & Total & 4 & 328009,588 & & & & & & \\
\hline & & $\begin{array}{c}\text { Coefficie } \\
\text { nts }\end{array}$ & $\begin{array}{c}\text { Standard } \\
\text { Error }\end{array}$ & t Stat & P-value & Lower 95\% & $\begin{array}{c}\text { Upper } \\
95 \%\end{array}$ & $\begin{array}{l}\text { Lower } \\
95,0 \%\end{array}$ & $\begin{array}{l}\text { Upper } \\
95,0 \%\end{array}$ \\
\hline & & 96,0973 & & 0,9445 & 0,41459 & 227,69682 & & - & \\
\hline & Intercept & 8 & 101,7438096 & 03 & & 8 & 419,8916 & 227,69683 & 419,89159 \\
\hline & & & 0,09711008 & 12,928 & 0,0009 & 0,9464557 & & 0,9464557 & \\
\hline & 1009,8 & 1,255503 & 3 & 66 & 99 & 9 & 1,564551 & 9 & 1,564551 \\
\hline
\end{tabular}

Source: calculated by the author.

Based on the analysis of Table 4, was found a very high correlation between GDP and Turnover of the non-financial business economy by size class of employment in all studied countries of Eastern Europe. This is explained by the fact that the coefficient of determination demonstrates high accuracy of approximation of variables, as in the six studied countries it is higher than 0.99, and in Ukraine - 0.98 .

The analysis of the coefficient of determination shows that in all the studied countries of Eastern Europe the variation of Turnover of the nonfinancial business economy by size class of employment is caused by the variation of GDP by more than 98-99. This is because the Turnover of the non-financial business economy by size class of employment has a very high impact on GDP growth.

\section{Discussion}

According to the results of the study, several approaches have been identified to highlight the importance of small and medium enterprises in the economic development of countries. In particular, it is established that the influence of small and medium enterprises on the economic growth of countries (for example, Eastern European countries) is reflected in the context of:
1) diversification and modernization of the economy, due to increasing rates of resource turnover and the formation and growth of the consumer market in conditions of limited resources and economic downturn [2];

2) transformation and development of communities [27];

3) providing optimal conditions for doing business, which will increase the competitiveness of the economy as a whole [1];

4) formation of special legislative conditions [30];

5) internationalization of small and medium enterprises [22];

6) development and implementation of several programs for financing (lending) activities of small and medium enterprises [3];

7) the impact of investment and innovation, resulting in increased efficiency of small and medium enterprises, which in the longrun has a positive impact on the economic development of the country as a whole [18];

8) impact on the development of digitalization of the economy due to the rapid development of innovation [29]; 
9) increasing the level of employment [32] and effective human resource management [23];

10) implementation of the principles of environmental management in the activities of small and medium enterprises[26] and compliance with the principles of environmental protection [33].

The above conclusions of the researchers should be agreed upon, but it should be noted that in practice the impact of small and medium enterprises on economic growth should be shown by studying the impact of small and medium enterprises on a key indicator of economic development - GDP.

Therefore, the study performed a regression analysis between the dependent variable GDP and the independent variable $R$.

The results of the regression analysis showed a very high relationship density and a very high relationship between GDP and Turnover of the non-financial business economy by size class of employment in all studied countries of Eastern Europe.

\section{Conclusions}

It has been found that small and medium-sized businesses are a key factor in the country's economic growth. It is established that the study of the impact of small and medium enterprises on the economic development of the country can be conducted using different approaches to assessing the dependence of the economy on the impact of small and medium enterprises.

Regression analysis to determine the impact of small and medium enterprises on economic growth should be carried out by establishing the dependence of GDP (GDP for Ukraine from Turnover of the non-financial business economy by size class of employment (Volume of sold products (goods, services) of small and medium enterprises belonging to the nonfinancial sector for Ukraine). As a result, was received a very high dependence of GDP from the Turnover of the non-financial business economy by size class of employment in all studied countries of Eastern Europe.

The practical significance of the results obtained in the study indicates that the proposed method for applying regression analysis to determine the dependence of the variable, which is a key indicator of economic development, on the independent variable as an indicator of small and medium enterprises can be adapted to another dependent (determine the economic development of countries) and independent (determine the performance of small and medium enterprises) variables.

Prospects for further research in this area will be a comprehensive study of the impact of small and medium enterprises on economic development in the context of increasing the competitiveness of the non-financial sector.

\section{References:}

[1] Angelova, M., \& Pastarmadzhieva, D. (2017). Challenges and opportunities for flexible crediting of small and medium-sized enterprises in Bulgaria. Fundamental Sciences and Applications, 23, 167-170.

[2] Akbarova, B. (2019). The role of small business and private entrepreneurship in the process of modernization and diversification of the economy. International Journal of Scientific \& Engineering Research, 10 (11), 911.

[3] Csiszárik-Kocsir, Á. (2017). Crisis and Financing - or the Practical Financing Decisions of Hungarian Small and Mediumsized Enterprises. Polgári Szemle: Gazdasági És Társadalmi Folyóirat, 13, 199-215. https://doi.org/10.24307/psz.2017.0312

[4] Derzhavna sluzhba statystyky Ukrainy (2021c). Dodana vartist za vytratamy vyrobnytstva pidpryiemstv za vydamy ekonomichnoi diialnosti z rozpodilom na velyki, seredni, mali ta mikropidpryiemstva (2010-2019). Retrieved from

www.ukrstat.gov.ua/operativ/operativ2020/fin/ pdp/pdp_ue/dvvvp_vsmm_2012-2019_ue.xlsx

[5] Derzhavna sluzhba statystyky Ukrainy (2021a). Kilkist pidpryiemstv za vydamy ekonomichnoi diialnosti z rozpodilom na velyki, seredni, mali ta mikropidpryiemstva (2010-2019). Retrieved from

www.ukrstat.gov.ua/operativ/operativ2018/fin/ pdp/pdp u/kp ek vsmm 20102018 u.xlsx

[6] Derzhavna sluzhba statystyky Ukrainy (2021b). Kilkist zainiatykh pratsivnykiv na pidpryiemstvakh za vydamy ekonomichnoi diialnosti z rozpodilom na velyki, seredni, mali ta mikropidpryiemstva (2010-2019). Retrieved 
from

www.ukrstat.gov.ua/operativ/operativ2019/fin/ pdp/pdp_u/kzp_ek_vsmm_2010_2019_u.xlsx

[7] Derzhavna sluzhba statystyky Ukrainy (2021e). Obsiah realizovanoi produktsii (tovariv, posluh) pidpryiemstv za vydamy ekonomichnoi diialnosti z rozpodilom na velyki, seredni, mali ta mikropidpryiemstva (2010-2019). Retrieved from

www.ukrstat.gov.ua/operativ/operativ2018/fin/ pdp/pdp u/orp ek vsmm 20102018 u.xlsx

[8] Derzhavna sluzhba statystyky Ukrainy (2021d). Valovyi vnutrishnii produkt (u faktychnykh tsinakh). Retrieved from http://www.ukrstat.gov.ua/

[9] Dobeš, K., Kot, S., Kramoliš, Ja., \& Sopková, G. (2017). The perception of governmental support in the context of competitiveness of SMEs in the Czech Republic. Journal of Competitiveness, $\quad 9(3), \quad 34-50$. https://doi.org/10.7441/joc.2017.03.03

[10] EU4Business (2021). Retrieved from https://eu4business.org.ua/

[11] EUR-Lex (2003). Commission Recommendation of 6 May 2003 concerning the definition of micro, small and medium-sized enterprises (Text with EEA relevance) (notified under document number C(2003) 1422) OJ L 124, 20.5.2003, p. 36-41 (ES, DA, DE, EL, EN, $F R, \quad I T, \quad N L, P T, F I, \quad S V)$. Retrieved from http://data.europa.eu/eli/reco/2003/361/oj

[12] Eurostat (2014). Glossary: Non-financial business economy. Retrieved from https://ec.europa.eu/eurostat/statisticsexplained/index.php/Glossary:Nonfinancial business economy

[13] Eurostat (2021a). The number of enterprises in the non-financial business economy by size class of employment. Retrieved from https://ec.europa.eu/eurostat/databrowser/view/ tin00145/default/table?lang=en

[14] Eurostat (2021b). Persons employed in the non-financial business economy by size class of employment. Retrieved from https://ec.europa.eu/eurostat/databrowser/view/ tin00148/default/table?lang=en

[15] Eurostat (2021d). Turnover of the nonfinancial business economy by size class of employment. Retrieved from https://ec.europa.eu/eurostat/databrowser/view/ tin00146/default/table?lang=en

[16] Eurostat (2021c). Value-added of the nonfinancial business economy by size class of employment.

Retrieved

from https://ec.europa.eu/eurostat/databrowser/view/ tin00147/default/table?lang=en

[17] Eurostat (2021e). GDP and main components (output, expenditure, and income). Retrieved from

https://ec.europa.eu/eurostat/databrowser/view/ NAMA 10 GDP custom 849107/default/tab le?lang=en

[18] Gherghina, S. C., Botezatu, M. A., Hosszu, A., \& Simionescu, L. N. (2020). Small and Medium-Sized Enterprises (SMEs): The Engine of Economic Growth through Investments and Innovation. Sustainability, 10(4). https://doi.org/10.3390/su12010347

[19] Ivanova, E. (2017). Barriers to the Development of SMEs in the Slovak Republic. Journal: Oeconomia Copernicana, 8 (2), 255272.

[20] Jaramillo, Ju. A., Sossa, J. W. Z., \& Mendoza, G. L. O. (2019). Barriers to sustainability for small and medium enterprises in the framework of sustainable development Literature review. Business Strategy and the Environment, 28(4), 512-524. https://doi.org/10.1002/bse.2261

[21] Kot, S. (2018). Sustainable Supply Chain Management in Small and Medium Enterprises. Sustainability, 10(4). https://doi.org/10.3390/su10041143

[22] Kowalik, I., Danik, L., Král, P., \& Řezanková H. (2017). Antecedents of Accelerated Internationalisation of Polish and Czech Small and Medium-Sized Enterprises. Entrepreneurial Business and Economics Review, 5(3), 31-48.

[23] Mura, L., Ključnikov, A., Tvaronavičienė, M., \& Androniceanu, A. (2017). Development Trends in Human Resource Management in Small and Medium Enterprises in the Visegrad Group. Acta Polytechnica Hungarica, 14(7), 105-122.

[24] Ndiaye, N., Razak, L. A., Nagayev, R., \& Ng., A. (2018). Demystifying small and medium enterprises (SMEs) performance in emerging and developing economies. Borsa Istanbul Review, 18(4), 269-281. https://doi.org/10.1016/j.bir.2018.04.003

[25] Papa, A., Santoro, G., Tirabeni, L., \& Monge, F. (2018). Social media as a tool for facilitating knowledge creation and innovation in small and medium enterprises. Baltic Journal of Management, $\quad$ 13(3), 329-344. https://doi.org/10.1108/BJM-04-2017-0125

[26] Raharjo, K. (2019). The role of green management in creating sustainability 
performance on the small and medium enterprises. Management of Environmental Quality, 30(3), 557-577. https://doi.org/10.1108/MEQ-03-2018-0053

[27] Ribeiro-Soriano, D. (2017). Small business and entrepreneurship: their role in economic and social development. Entrepreneurship \& Regional Development, 29(1-2). https://doi.org/10.1080/08985626.2016.125543 $\underline{8}$

[28] Š Sebestová, Ja., \& Sroka, W. (2020). Sustainable development goals and SMEs decisions: the Czech Republic vs. Poland. Journal of Eastern European and Central Asian Research, 7(1), 39-50. https://doi.org/10.15549/jeecar.v7i1.418

[29] Shokhnekh, A. V., Telyatnikova, V. S., Pozdeev, V. L., Nosov, A. L., \& Mushketova, N. S. (2019). Concept Strategy of Innovative Small Business in the System of Economic Security of the Digital Economy. Growth Poles of the Global Economy: Emergence, Changes and Future Perspectives, 73, 1397-1406. https://doi.org/10.1007/978-3-030-151607143

[30] Strazovska, L. U., \& Jancikova, E. (2017). New regulations and their impact on small and medium enterprises in Slovak Republic. Aktual'ni Problemy Ekonomiky, 3(189), 90-97.

[31] Umadia, K. Sr., \& Kasztelnik, K. (2020). The Financial Innovative Business Strategies of Small to Medium Scale Enterprises in Developing Country and Influence for the Global Economy Performance. SocioEconomic Challenges, $\quad 4(3), \quad 20-32$. https://doi.org/10.21272/sec.4(3).20-32.2020

[32] Vlacseková, D., \& Mura, L. (2017). Effect of motivational tools on employee satisfaction in small and medium enterprises. Journal: Oeconomia Copernicana, 8(1), 111-130.

[33] Woodard, R. (2021). Waste Management in Small and Medium Enterprises (SMEs): Compliance with Duty of Care and implications for the Circular Economy. Journal of Cleaner Production, 278(1). https://doi.org/10.1016/j.jclepro.2020.123770

[34] World Bank (2020). Doing Business 2020. Retrieved from http://documents1.worldbank.org/curated/en/68 8761571934946384/pdf/Doing-Business-2020Comparing-Business-Regulation-in-190Economies.pdf

\section{Contribution of Individual Authors to the Creation of a Scientific Article (Ghostwriting Policy)}

Petrunenko Iaroslav, scrubbed data and maintain research data for initial use and later re-use.

Iryna Khmarska, Tetiana Tkachenko carried about writing the initial draft.

Hanna Koptieva, Veronika Komandrovska was responsible for the regression analysis

\section{Sources of Funding for Research Presented in a Scientific Article or Scientific Article Itself}

There aren't any sources of funding for research presented in the article.

Creative Commons Attribution License 4.0 (Attribution 4.0 International, CC BY 4.0)

This article is published under the terms of the Creative Commons Attribution License 4.0 https://creativecommons.org/licenses/by/4.0/deed.en US 